\title{
Editorial 2012: shaping the profile of Journal of Pest Science
}

\author{
Michael Traugott - Christos Athanassiou - Chris Cutler • Nicolas Desneux • \\ A. Rami Horowitz - Rainer Meyhöfer - Les Shipp - Christian Stauffer • \\ Donald C. Weber $\cdot$ Myron P. Zalucki
}

Received: 2 February 2012/ Accepted: 7 February 2012/Published online: 15 February 2012

(C) Springer-Verlag 2012

Journal of Pest Science covers all aspects of pest control providing it with a broad thematic standing (Traugott and Gross 2008; Traugott 2010). Nevertheless, the team of editors is always keen to shape the journal's profile, and therefore we have modified the aims and scope to carve out a clear profile for Journal of Pest Science. Our current aims and scope are to publish high-quality papers on all aspects of pest science in agriculture, horticulture (including viticulture), forestry, urban pests, and stored products research, including health and safety issues.

Journal of Pest Science reports on advances in control of pests and vectors of diseases, the biology, ethology and ecology of pests and their antagonists, and the use of other beneficial organisms in pest control. The journal covers all

\section{Traugott $(\bowtie)$}

Mountain Agriculture Research Unit, Institute

of Ecology, University of Innsbruck, Technikerstrasse 25,

6020 Innsbruck, Austria

e-mail: Michael.Traugott@uibk.ac.at

\section{Athanassiou}

Laboratory of Entomology and Agricultural Zoology,

Department of Agriculture, Crop Production and Rural

Environment, University of Thessaly, Phytokou str,

38446 N. Ionia, Magnesia, Greece

\section{Cutler}

Department of Environmental Sciences, Nova Scotia

Agricultural College, P.O. Box 550, Truro NS B2N 5E3, Canada

\section{N. Desneux}

French National Institute for Agricultural Research (INRA), 400 route des chappes, Sophia-Antipolis, France

\section{A. Rami Horowitz}

Department of Entomology, Agricultural Research Organization (ARO), Gilat Research Center, 85280 Mobile Post Negev, Israel noxious or damaging organisms, including arthropods, nematodes, molluscs, vertebrates, plant pathogens, and weeds.

Journal of Pest Science devotes special attention to emerging and innovative pest control strategies, including the side effects of such approaches on non-target organisms, for example natural enemies and pollinators, and the implementation of these strategies in integrated pest management.

Journal of Pest Science also publishes papers on the management of agro- and forest ecosystems where this is relevant to pest control. Papers on technical developments relevant for pest control will be considered as well.

Moreover, the journal welcomes commentaries on pressing topics in pest control, as for example the current

\section{R. Meyhöfer}

Institute of Plant Diseases and Plant Protection, Leibniz

Universität Hannover Herrenhäuser Strasse 2, 30419

Hannover, Germany

\section{Shipp}

Agriculture and Agri-Food Canada, Greenhouse and Processing

Crops Research Centre, Harrow, ON NOR 1G0, Canada

C. Stauffer

Institute of Forest Entomology, Forest Pathology and Forest Protection, Boku, University of Natural Resources and Life

Sciences, Hasenauerstrasse 38, 1190 Wien, Austria

D. C. Weber

Invasive Insect Biocontrol and Behavior Laboratory, USDA

Agricultural Research Service, BARC-West Building 011A,

Beltsville, MD 22207, USA

M. P. Zalucki

School of Biological Sciences, The University of Queensland,

Brisbane 4072, Australia 
spread of invasive pests (e.g., Desneux et al. 2011). These articles will be fast-tracked, to rapidly provide scientists, and pest control practitioners with the latest information.

Themes where submissions are encouraged include the following:

Pests and natural enemies of importance across wide regions or globally such as aphids, whiteflies, or wireworms (e.g., Noronha et al. 2008)

Biology and management of major invasive pests (e.g., Suckling and Brockerhoff 2010), including non-arthropod groups such as vertebrates and weeds (e.g., Benvenuti 2007)

Determination of damage and economic thresholds, as they may vary across crops, commodities, cultivars, and cultural practices as well as host plant resistance (e.g., Crowder et al. 2006)

Works that investigate pest and natural enemy biology and ecology as well as pest management in a landscape context (e.g., Petrovan et al. 2011)

Novel tactics or strategies of pest management, their application, advantages and disadvantages, for example pollinator-mediated dispersal of biocontrols (e.g., Mommaerts et al. 2011) or cultural practices encouraging biological control

Applications of pheromones and other semiochemicals to pest management (e.g., Witzgall et al. 2008)

Integrated pest management (IPM) including biological, physical, chemical, and other methods of control, preferably applied in combination (e.g., Athanassiou et al. 2011). The journal would also welcome wider studies dealing with approaches and incentives for effective, environmentally and economically sound implementation of IPM (for review see Brewer and Goodell 2012)

Phytochemicals and botanical pesticides (for review see Regnault-Roger et al. 2012) which are increasingly important for pest management (e.g., Sik et al. 2011)

Studies utilizing new techniques or advances in pest and natural enemy sampling, detection, monitoring, and forecasting as well as for studying species interactions (e.g., Hoddle et al. 2011)

Impacts of pest management on the environment and its biodiversity, side effects of pesticides on natural enemies, and other beneficial organisms such as pollinators (e.g., Brittain et al. 2010) that are key for biocontrol and pollination services (for review see Desneux et al. 2007), including the opportunities and limitations for use of genetically modified organisms in pest management (e.g., Chen et al. 2011)

Impact of climate change on all aspects of pest control (e.g., Kocmankova et al. 2010)
Decision making and modelling in pest management (e.g., Wesseler and Fall 2010)

Review papers on current topics of pest control strategies as well as on pest and natural enemy biology and ecology (e.g., Daane and Johnson 2010; Desneux et al. 2010; Ragsdale et al. 2011)

In contrast to the topics outlined above, we will not publish preliminary works or studies which are primarily of confirmatory nature. Simple laboratory bioassay data of chemical or biological agents will only be considered if the work is novel and/or shows unexpected effects, if it compares susceptibility of life stages or species, or compares efficacy delivered by different formulations tested in parallel. In addition, we might consider works which provide a comprehensive analysis of the efficacy of multiple pathogens against multiple target pests.

We strongly advise non-English speakers to have their manuscripts edited by a native English speaker for fluency and grammar before submission, as manuscripts which have shortcomings in language will not be considered for peer-review.

We invite prospective authors to clearly explain why the work is novel and how it advances knowledge of pests and their management. Moreover, the general implications of the work for the broader subject area should be explained. The objectives and the hypotheses of the work must be clearly stated and put into context. All experimental work needs to be properly designed to test the questions posed, and to contain proper statistical analysis of the data. Within the "Discussion" section, the results should again be put into context with current knowledge, and the implications for pest management presented. We advise authors to evaluate management practice at more than one location and for more than 1 year to achieve meaningful results.

We hope that these guidelines will be helpful to our future authors and to further increase the quality and reputation of Journal of Pest Science as a prime outlet for pest management research.

\section{References}

Athanassiou CG, Arthur FH, Kavallieratos NG, Throne JE (2011) Efficacy of spinosad and methoprene, applied alone or in combination, against six stored-product insect species. J Pest Sci 84:61-67

Benvenuti S (2007) Weed seed movement and dispersal strategies in the agricultural environment. Weed Biol Manag 7:141-157

Brewer MJ, Goodell PB (2012) Approaches and incentives to implement integrated pest management that addresses regional and environmental issues. Annu Rev Entomol 57:41-59

Brittain C, Bommarco R, Vighi M, Barmaz S, Settele J, Potts SG (2010) The impact of an insecticide on insect flower visitation and pollination in an agricultural landscape. Agr Forest Entomol $12: 259-266$ 
Chen LZ, Cui JJ, Ma WH, Niu CY, Lei CL (2011) Pollen from Cry1Ac/CpTI-transgenic cotton does not affect the pollinating beetle Haptoncus luteolus. J Pest Sci 84:9-14

Crowder DW, Onstad DW, Gray ME (2006) Planting transgenic insecticidal corn based on economic thresholds: consequences for integrated pest management and insect resistance management. J Econ Entomol 99:899-907

Daane KM, Johnson MW (2010) Olive fruit fly: managing an ancient pest in modern times. Annu Rev Entomol 55:151-169

Desneux N, Decourtye A, Delpuech JM (2007) The sublethal effects of pesticides on beneficial arthropods. Annu Rev Entomol 52:81-106

Desneux N, Wajnberg E, Wyckhuys KAG, Burgio G, Arpaia S, Narváez-Vasquez CA, González-Cabrera J, Catalán Ruescas D, Tabone E, Frandon J, Pizzol J, Poncet C, Cabello T, Urbaneja A (2010) Biological invasion of European tomato crops by Tuta absoluta: ecology, history of invasion and prospects for biological control. J Pest Sci 83:197-215

Desneux N, Luna MG, Guillemaud T, Urbaneja A (2011) The invasive South American tomato pinworm, Tuta absoluta, continues to spread in Afro-Eurasia and beyond-the new threat to tomato world production. J Pest Sci 84:403-408

Hoddle MS, Millar JG, Hoddle CD, Zou Y, McElfresh JS, Lesch SM (2011) Field optimization of the sex pheromone of Stenoma catenifer (Lepidoptera: Elachistidae): evaluation of lure types, trap height, male flight distances, and number of traps needed per avocado orchard for detection. B Entomol Res 101:145-152

Kocmankova E, Trnka M, Eitzinger J, Formayer H, Dubrovsky M, Semeradova D, Zalud Z, Juroch J, Mozny M (2010) Estimating the impact of climate change on the occurrence of selected pests in the Central European region. Clim Res 44:95-105
Mommaerts V, Put K, Smagghe G (2011) Bombus terrestris as pollinator and vector to suppress Botrytis cinerea in greenhouse strawberry. Pest Manag Sci 67:1069-1075

Noronha C, Vernon RS, Vincent C (2008) Key pests of potatoes in Canada. Cah Agric 17:375-381

Petrovan SO, Barrio IC, Ward AI, Wheeler PM (2011) Farming for pests? Local and landscape-scale effects of grassland management on rabbit densities. Eur J Wildlife Res 57:27-34

Ragsdale DW, Landis DA, Brodeur J, Heimpel GE, Desneux N (2011) Ecology and management of the soybean aphid in North America. Annu Rev Entomol 56:375-399

Regnault-Roger C, Vincent C, Arnason JT (2012) Essential oils in insect control: low-risk products in a high-stakes world. Annu Rev Entomol 57:405-424

Sik H, Lim EG, Kim J, Park CG (2011) Acaricidal and oviposition deterring effects of santalol identified in sandalwood oil against two-spotted spider mite, Tetranychus urticae Koch (Acari: Tetranychidae). J Pest Sci 84:495-501

Suckling DM, Brockerhoff EG (2010) Invasion biology, ecology, and management of the light brown apple moth (Tortricidae). Annu Rev Entomol 55:285-306

Traugott M (2010) Editorial 2010. J Pest Sci 83:1-2

Traugott M, Gross J (2008) News from the Editor-in-Chief. J Pest Sci $81: 1-2$

Wesseler J, Fall EH (2010) Potential damage costs of Diabrotica virgifera virgifera infestation in Europe-the 'no control' scenario. J Appl Entomol 134:385-394

Witzgall P, Stelinski L, Gut L, Thomson D (2008) Codling moth management and chemical ecology. Annu Rev Entomol $53: 503-522$ 